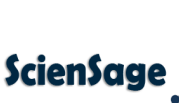

Journal of Advanced Scientific Research

Available online through https: / /sciensage.info
ISSN: 0976-9595

Research Article

DOI: $10.55218 /$ JASR. 202213132

\title{
DEVELOPMENT AND VALIDATION OF RP-HPLC METHOD FOR SIMULTANEOUS ESTIMATION OF SOFOSBUVIR AND VELPATASVIR IN BULK AND TABLET DOSAGE FORM
}

\author{
Pinnoju Srawanthi, Sireesha Dodda*, Jainendra Kumar Battineni \\ School of Pharmacy, Anurag University (Formerly Anurag Group of Institutions), Hyderabad, Telangana, India \\ *Corresponding author: sireeshapharmacy@cvsr.ac.in
}

\begin{abstract}
A simple, accurate, sensitive reverse phase high performance liquid chromatography (RP-HPLC) method was developed for the simultaneous estimation of the Sofosbuvir and Velpatasvirin bulk and tablet dosage form. Separation of the analytes was carried out by using Kromasil C18 $(250 \times 4.6 \mathrm{~mm}, 5 \mu \mathrm{m})$ column with HPLC grade methanol as mobile phase at aflow rate of $1.0 \mathrm{~mL} / \mathrm{min}$ within the run time of $4 \mathrm{~min}$. The detection wavelength selected was $261 \mathrm{~nm}$ for Sofosbuvir (SOF) and 303nm for Velpatasvir (VEL). The retention times of SOF and VEL were $2.57 \mathrm{~min}$ and $2.86 \mathrm{~min}$, respectively. The linearity of the method was found in the concentration range of $2.0-40.0 \mu \mathrm{g} / \mathrm{mL}$ for SOF and 2.0 $25.0 \mu \mathrm{g} / \mathrm{mL}$ for VEL with correlation coefficient $\left(\mathrm{R}^{2}\right)>0.99$. The method was validated according to ICH guidelines. This method was also successfully employed for the simultaneous estimation of SOF and VEL in marketed formulation.
\end{abstract}

Keywords: Sofosbuvir, Velpatasvir, RP-HPLC, Method validation, Simultaneous estimation.

\section{INTRODUCTION}

Hepatitis $\mathrm{C}$ is a liver infection that can lead to serious liver damage. Sofosbuvir and Velpatasvir are the drugs used in the treatment of Hepatitis $\mathrm{C}$ virus (HCV) in combinational therapy [1, 2]. Sofosbuvir is chemically isopropyl (2s)-2[[[(2R,3R,4R,5R)-5-(2,4dioxop[yrimidin-1-yl)-4-fluoro-3-hydroxy-4-methyl-tetra hydro furan-2-yl] methoxy-phenoxy-phosphoryl] amino] pro-pionate (Fig 1A). It is a prodrug and its active form inhibits viral RNA synthesis by acting on Hepatitis C
NS5B protein [3-5]. Velpatasvir is chemically Methyl $\{(2 \mathrm{~S})-1-[(2 \mathrm{~S}, 5 \mathrm{~S})-2-(9-\{2-[(2 \mathrm{~S}, 4 \mathrm{~S})-1-\{(2 \mathrm{R})-2-[($ methoxycarbonyl)amino]-2-phenylacetyl $\}-4-($ methoxymethyl)2pyrrolidinyl]-1H-imidazol-4-yl $\}$-1, 11-dihydroiso-chromeno[4', 3':6,7]naphtha[1,2-d] imidazol-2-yl)-5-methyl1-pyrrolidinyl]-3-methyl-1-oxo-2-butanyl $\}$ carbamate (Fig 1B). Velpatasvir is an inhibitor of HCV NS5A protein, which blocks the action of the protein and thus inhibits the viral replication [6, 7].
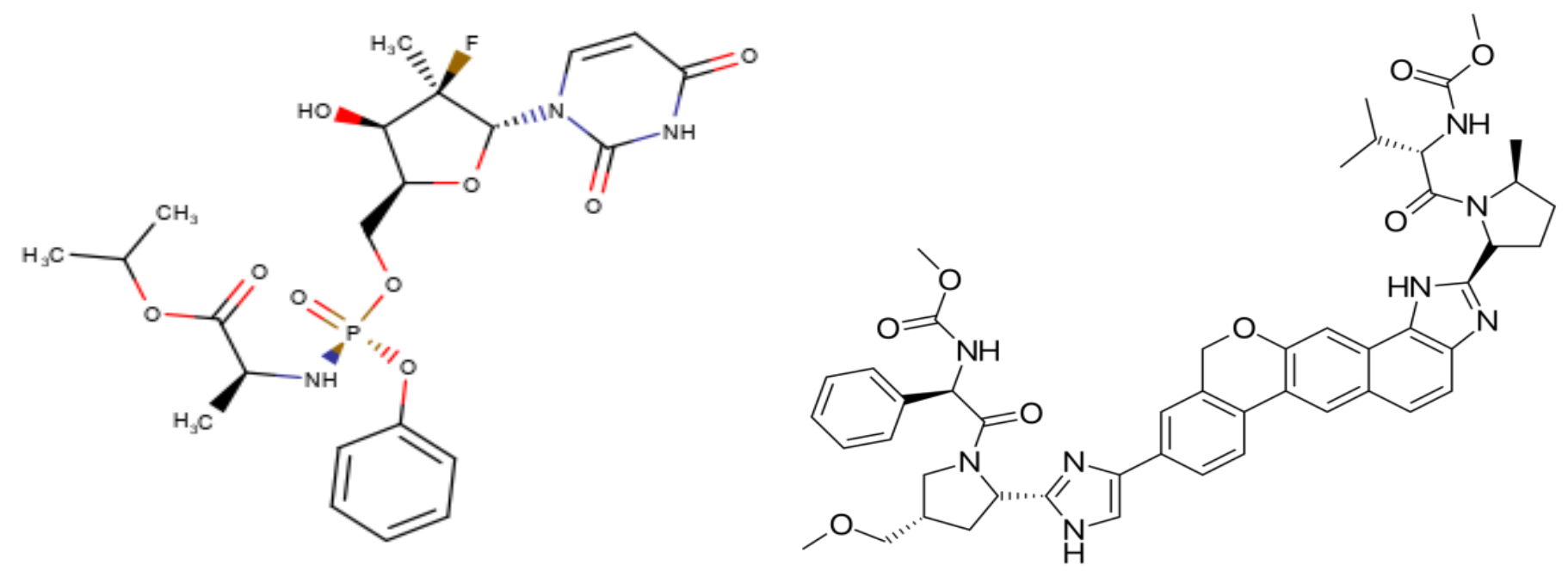

Fig. 1: Chemical Structures of Sofosbuvir (A) and Velpatasvir (B) 
The literature survey reveals that the methods were reported for the simultaneous estimation of SOF and VEL by RP-HPLC in bulk and tablet dosage form [815]. However, all these reported methods have less sensitivity with established linearity range from $\geq 10$ $\mu \mathrm{g} / \mathrm{mL}$ for Sofosbuvir or longer chromatographic run time and usage of mixture of solvents as mobile phase. The present method describes simultaneous estimation of Sofosbuvir and Velpatasvir in bulk and tablet dosage form by RP-HPLC. The proposed method has higher sensitivity with linearity range established from $2 \mu \mathrm{g} / \mathrm{mL}$ for both the analytes, used only methanol as mobile phase within a chromatographic run time of $4 \mathrm{~min}$.

\section{EXPERIMENTAL}

\subsection{Reagents and Chemicals}

The working standards of Sofosbuvir and Velpatasvir were supplied by Hetero Drugs Pvt Ltd, Hyderabad. HPLC Grade methanol was supplied by Research-Lab fine Chem industries, Mumbai. VELASOF tablets (Label claim: Sofosbuvir-400mg and Velpatasvir- 100mg) manufactured by Hetero Drugs Pvt Ltd, Hyderabad were purchased from local pharmacy.

\subsection{Chromatographic Conditions}

A Prominence HPLC (Shimadzu, Kyoto, Japan) with binary LC-20AD prominence pump and PDA detector equipped with Kromasil C18 (250 x 4.6mm, $5 \mu \mathrm{m})$ column was used for the present study. HPLC grade methanol was used as mobile phase at a flow rate of 1.0 $\mathrm{mL} / \mathrm{min}$. The injection volume was $20 \mu \mathrm{L}$. The eluents were measured at $261 \mathrm{~nm}$ for Sofosbuvir and $303 \mathrm{~nm}$ for Velpatasvir. The data analysis was done using Lab Solutions Software.

\subsection{Preparation of Standard solutions}

Primary stock solutions were prepared by dissolving $100 \mathrm{mg}$ of each of working standards of Sofosbuvir and Velpatasvir separately in $100 \mathrm{~mL}$ methanol to get the concentration of $1000 \mu \mathrm{g} / \mathrm{ml}$. From these stock solutions, combined working standard solutions were prepared in the concentration range of $2.0-40 \mu \mathrm{g} / \mathrm{mL}$ for SOF and 2.0-25 $\mu \mathrm{g} / \mathrm{mL}$ for VEL.

\subsection{Preparation of Sample solution}

Twenty tablets of VELASOF were weighed and powdered. The powder equivalent to $100 \mathrm{mg}$ of SOF was transferred into a $100 \mathrm{ml}$ volumetric flask and methanol was added and then sonicated for $20 \mathrm{~min}$. The final volume was then made up to the mark with the same solvent and filtered. Filtrate of $1 \mathrm{~mL}$ was diluted to $100 \mathrm{~mL}$ using methanol to get the concentration of $10 \mu \mathrm{g} / \mathrm{mL}$.

\subsection{Method validation}

The developed method was validated as per ICH guidelines [16]. The parameters evaluated during validation were linearity, precision, accuracy, limit of detection and limit of quantification and robustness.

\section{RESULTS AND DISCUSSION}

\subsection{Method development}

The chromatographic conditions to be optimized are mobile phase selection, flow rate and type of column to achieve efficient separation and to obtain sharp peak shape, adequate peak response in a short run time. HPLC grade methanol was tried using Zorbax $\mathrm{SB} \mathrm{C}_{18}$ (250 x $4.6 \mathrm{~mm}, 5 \mu \mathrm{m})$, Ace Phenyl Column $(150 \times 4.6$ $\mathrm{mm}, 5 \mu \mathrm{m})$ and Kromasil C18 $(250 \mathrm{x} 4.6 \mathrm{~mm}, 5 \mu \mathrm{m})$ column at different flow rates. The use of Kromasil C18 $(250 \times 4.6 \mathrm{~mm}, 5 \mu \mathrm{m})$ column helped in efficient separation with HPLC grade methanol as mobile phase at flow rate of $1.0 \mathrm{~mL} / \mathrm{min}$ within a short run time of 4 min. Detection of eluents was carried out at $\lambda$ max of $261 \mathrm{~nm}$ and $303 \mathrm{~nm}$ for SOF and VEL, respectively. The optimized chromatogram is shown in Fig. 2.

\subsection{Linearity \& Range}

Linearity was assessed by performing analysis of calibration curve standards in the concentration range of $2-40 \mu \mathrm{g} / \mathrm{ml}$ for Sofosbuvir and $2-25 \mu \mathrm{g} / \mathrm{ml}$ for Velpatasvir. The correlation coefficient $\left(\mathrm{R}^{2}\right)$ found was $>0.99$ (Fig. 3).

\subsection{Precision}

The intra-day and inter-day precision studies were carried out by six replicate injectionsof the working standard solutions on the same day and different days, respectively. The method was found to be robust with $\%$ RSD values within the range of 1.44 to $1.84 \%$ (Table 1).

\subsection{Accuracy}

Accuracy studies are performed by spiking the blank with both the analytes at $80 \%, 100 \%$ and $120 \%$ levels. The \% recovery was calculated to be in the range of 98.80 to $101.82 \%$ (Table 2). 


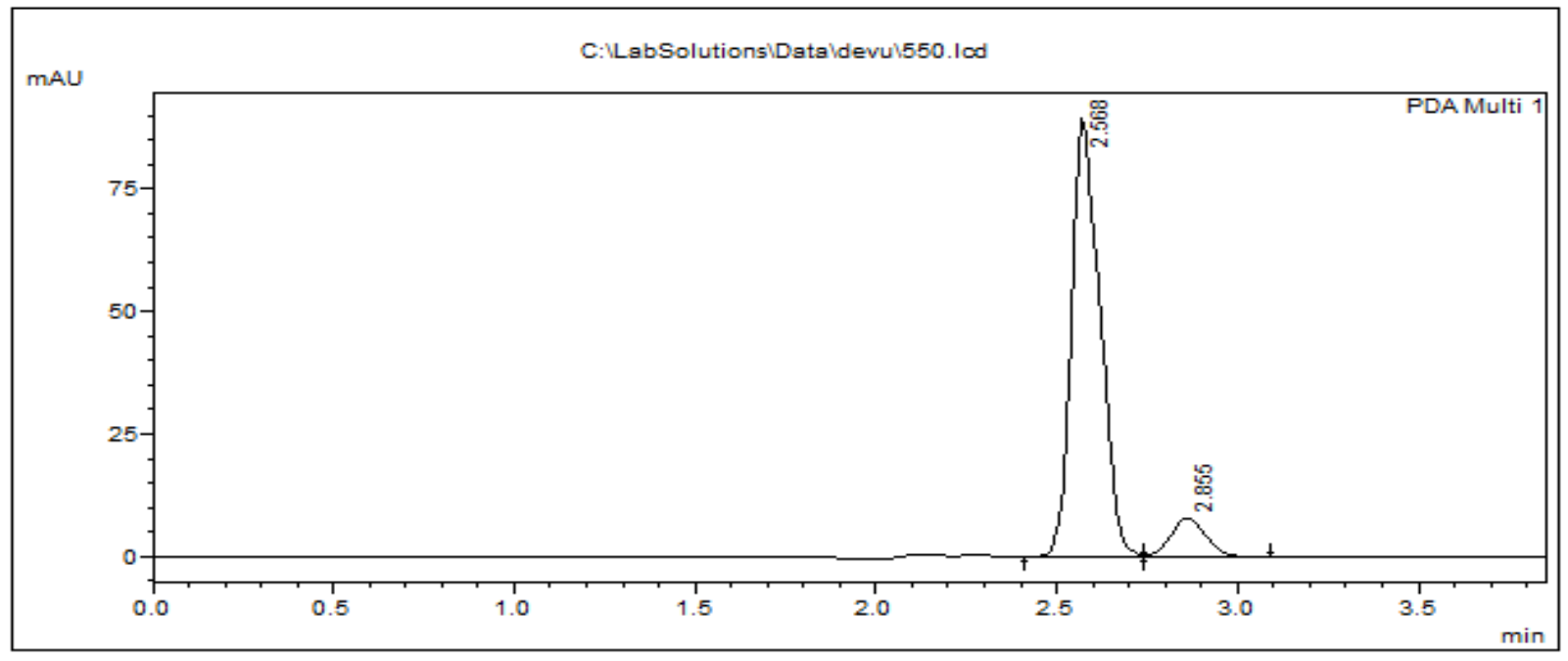

Fig. 2: Optimized Chromatogram of Sofosbuvir and Velpatasvir

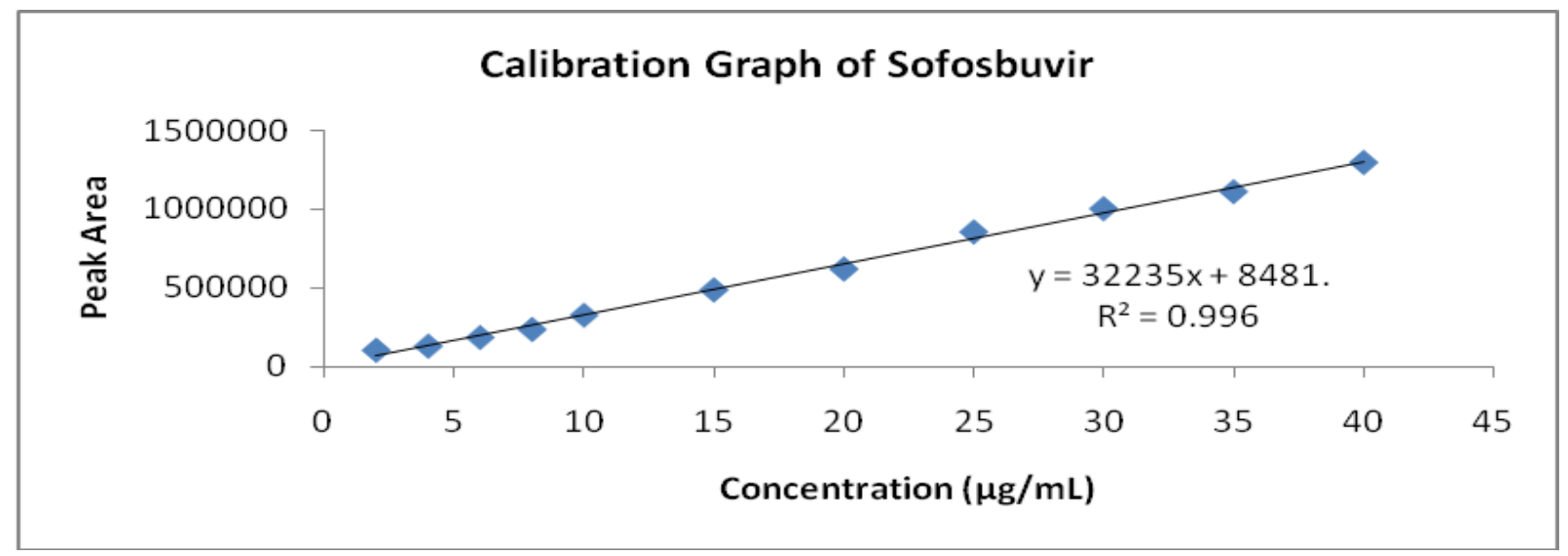

(A)

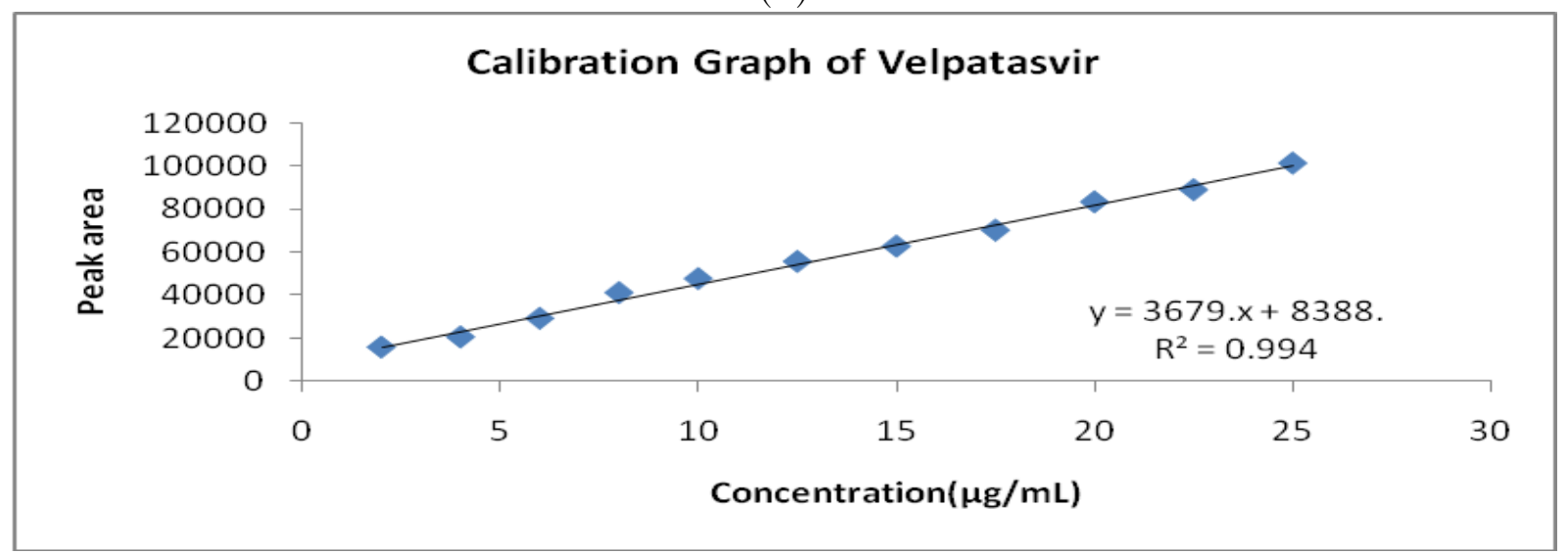

(B)

Fig. 3: Calibration curves of A) Sofosbuvir and B) Velpatasvir

Table 1: Precision Data

\begin{tabular}{ccccc}
\hline Drug & Parameter & Mean Peak area & Standard Deviation & RSD (\%) \\
\hline \multirow{2}{*}{ Sofosbuvir } & Intra-day precision & 326160.2 & 4787.99 & 1.46 \\
\cline { 2 - 5 } & Inter-day precision & 322849.83 & 4650.92 & 1.44 \\
\hline \multirow{2}{*}{ Velpatasvir } & Intra-day precision & 47204.33 & 796.93 & 1.68 \\
\cline { 2 - 5 } & Inter-day precision & 46516.5 & 859.46 & 1.84 \\
\hline
\end{tabular}




\subsection{Robustness}

The robustness of the proposed method was evaluated by small and deliberate changes in flow rate and there was no significant change in the results, proved that the method is robust.

\subsection{Limit of detection and Limit of quantification}

LOD and LOQ were calculated using signal to noise ratios of 3:1 and 10:1, respectively. The LOD and LOQ values were found to be $0.49 \mu \mathrm{g} / \mathrm{mL}$ and $1.48 \mu \mathrm{g} / \mathrm{mL}$ for sofosbuvir, and $0.72 \mu \mathrm{g} / \mathrm{mL}$ and $2.16 \mu \mathrm{g} / \mathrm{mL}$ for velpatasvir, respectively.

\subsection{Analysis of Marketed Formulation}

The developed method was applied to quantitatively estimate the concentration of both the analytes simultaneously in the marketed formulation. The sample solution was assayed using the developed method and \% assay was calculated. The results are shown in Fig. 4 and Table 3.

Table 2: Accuracy Data

\begin{tabular}{|c|c|c|c|c|}
\hline Drug & Level & $\begin{array}{c}\text { Concentration Added } \\
(\mu \mathrm{g} / \mathrm{ml})\end{array}$ & $\begin{array}{c}\text { Concentration recovered } \\
\qquad(\mu \mathrm{g} / \mathrm{ml})\end{array}$ & \% Recovery \\
\hline \multirow{3}{*}{ Sofosbuvir } & 80 & 18 & 17.7 & 98.80 \\
\hline & 100 & 20 & 19.80 & 99.04 \\
\hline & 120 & 22 & 22.4 & 101.82 \\
\hline \multirow{3}{*}{ Velpatasvir } & 80 & 4.5 & 4.49 & 99.80 \\
\hline & 100 & 5.0 & 5.06 & 101.20 \\
\hline & 120 & 5.5 & 5.59 & 101.70 \\
\hline
\end{tabular}

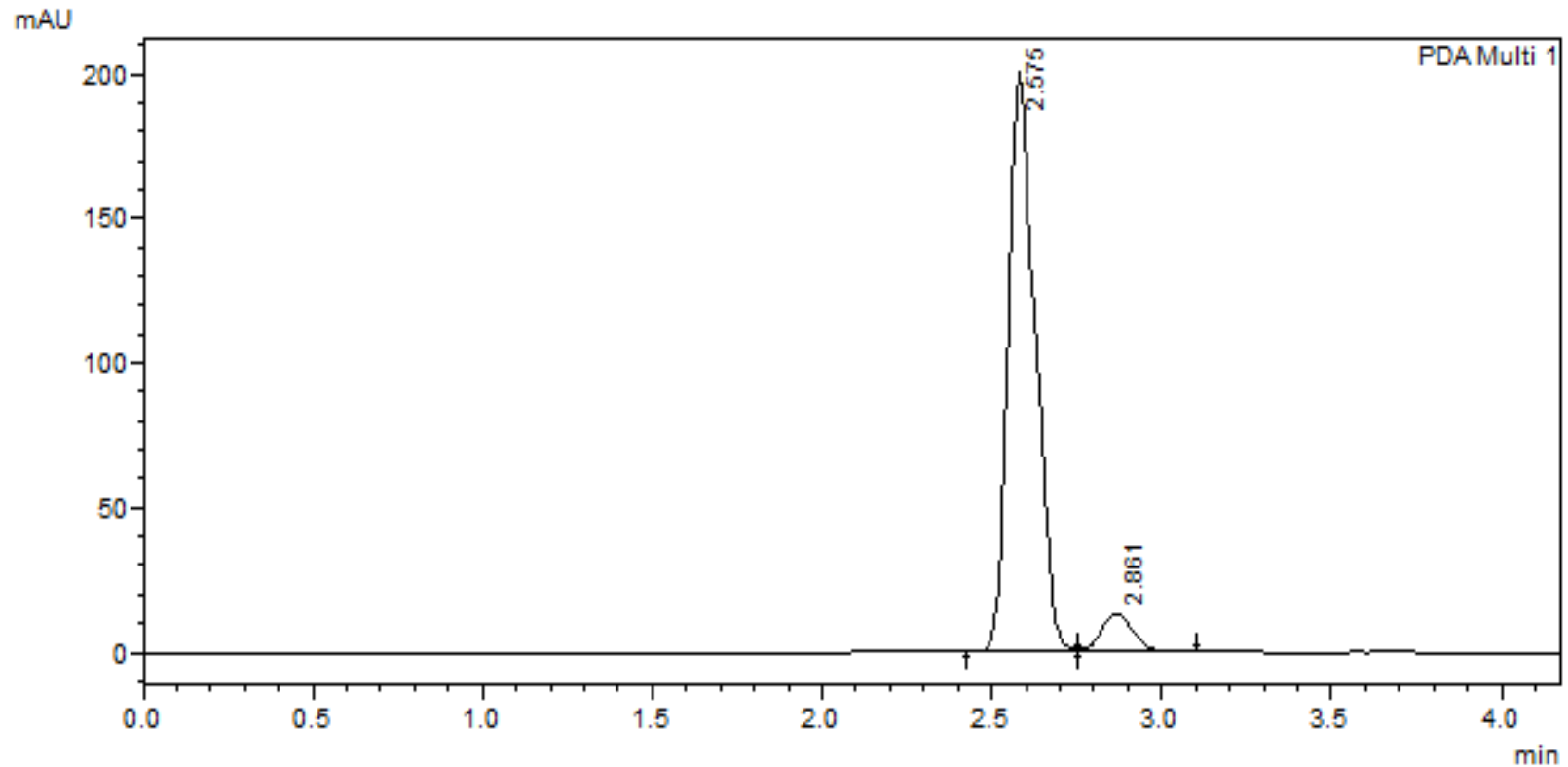

Fig. 4: Chromatogram of Marketed formulation

Table 3: Assay results of marketed tablet dosage form

\begin{tabular}{cccc}
\hline Drug & $\begin{array}{c}\text { Label claim } \\
\text { (mg/Tablet) }\end{array}$ & $\begin{array}{c}\text { Amount } \\
\text { found (mg/ } \\
\text { Tablet) }\end{array}$ & $\begin{array}{c}\text { Assay } \\
\mathbf{( \% )}\end{array}$ \\
\hline Sofosbuvir & 400 & 396.9 & 99.2 \\
\hline Velpatasvir & 100 & 98.9 & 98.9 \\
\hline
\end{tabular}

\section{CONCLUSION}

A simple, precise, accurate method was developed for the simultaneous analysis of sofosbuvir and velpatasvir in bulk and tablet dosage form. HPLC grade methanol used as the mobile phase made the method more economical and also eliminating the usage of buffers improved the life-time of the column. The runtime of $4.0 \mathrm{~min}$ enables rapid analysis of samples in routine 
quality control tests. Hence, the developed method can be successfully applied to routine simultaneous analysis of Sofosbuvir and Velpatasvir in bulk and combined tablet dosage forms.

\section{ACKNOWLEDGEMENTS}

The authors are thankful to Anurag University, Hyderabad for providing necessary facilities to carry out the research work.

\section{Conflicts of interest}

The authors declare that there is no conflict of interest.

\section{REFERENCES}

1. Bonaventura A and Montecucco F. World J Hepatol, 2016; 8(19):785-789.

2. Curry MP, O'Leary JG, Bzowej N, Muir AJ, Korenblat KM, Fenkel JM et al. N Engl J Med, 2015; 373(27):2618-2628.

3. Keating GM, VaidyaA. Drugs, 2014; 74(2):273282.

4. Lawitz E, Mangia A, Wyles D. $N$ Engl J Med, 2013; 368(20):1878-1887.

5. Cholongitas E and Papatheodoridis GV. Ann Gastroenterol, 2014; 27(4):331-337.

6. Everson GT, Towner WJ, Davis MN, Wyles DL, Nahass RG, Thuluvath PJ et al. Ann Intern Med, 2015; 163(11):818-826.

7. Feld JJ, Jacobson IM, Hézode C, Asselah T, Ruane
PJ, Gruener $\mathrm{N}$ et al. $N$ Engl J Med, 2015; 373(27):2599-2607.

8. Sreehitha V, Sireesha R, Sivagami B, Kumar VP, Chandrasekar R, Babu MN. Int J Res Dev Pharm L Sci, 2018; 7(5):3092-3099.

9. Padmavathi S, Sravanthi G, Saisrilakshmi G, Naga Varalakshmi T, Vani T. Int J Cur Adv Res, 2018; 7(6):13750-13756.

10. Kalpana N, Shanmukha Kumar JV, Ramachandran D. Asian J Pharm Clin Res, 2018; 11(2):164-168.

11. Revathi K, Sowndarya G, Swathi V. Int J Adv Pharm Biotech, 2020; 6(3):19-22.

12. Yasir M, Ikram UK, Yasser S, Syed HK, Muhammad I, Sajid A et al. Pak J Pharm Sci, 2019; 32 Suppl 4:1835-1842.

13. Sandya Rani J, Devanna N. Int J Eng Tech Sci Res, 2017; 4(11):145-152.

14. Ramreddy G, Sowjanya G. Int J Pharm Sci Res, 2020; 11(11):5669-5678.

15. Mamatha J, Devanna N. Rasayan J Chem, 2018; 11(1):392- 400

16. Jaimin PP, Ankit BC. World J Pharm PharmSci, 2018; 7(5):813-828.

17. ICH, 2005. Q2 (R1), "Validation of analytical procedures: text and methodology", ICH Harmonised Tripartite Guideline. International Conference on Harmonisation of Technical Requirements for Registration of Pharmaceuticals for Human Use, Chicago, USA, 2005. 